\title{
Economic Analysis of Marketing of Summer Groundnut in Hingoli district of Maharashtra State, India
}

\author{
D.B. Chatse*, D.S. Perke and R.D. Selke \\ Department of Agricultural Economics, Vasantrao Naik Marathwada Krishi Vidyapeeth, \\ Parbhani (M.S.), India \\ *Corresponding author
}

K e y w o r d s
Marketing channel,
Marketing cost,
Market margin and
Price spread

A B S T R A C T

The study examined that marketing of groundnut in Hingoli district of Maharashtra state. In present study cost incurred by producer, wholesaler and retailer in groundnut marketing shows that higher production sold in channel III (144.4q.) followed by channel II (73.18 q.) and channel I (69.18q) The highest production sold in channel III followed by channel III and channel I, respectively. Production, retention and marketed surplus of groundnut sold through different channels were Production of TAG-24 groundnut was 29.50 quintals on 1.64 hectares and SB-11 groundnut 32.05 and its retention for home on TAG-24 was 2.95 and SB-11 was 2.25 quintals. The results revealed that quantity of TAG-24 groundnut as 12.10, and SB-11 12.40 quintals were marketed through channel-I, 9.25 and 11.45quintals in channel-II, 4.65 and 2.55 and channel-I with percentage TAG-24 and SB-11 groundnut 41.00 and 43.28 in channel I, 30.45 and 40.25 in channel II and 16.30 and 8.90 in Channel III, respectively. Thus total marketed surplus of TAG-24 groundnut was 96.61 per cent and 89.39 per cent on SB-11 groundnut. Per quintal marketing cost, marketing margin and price spread in groundnut marketing with respect to different channels. In channel-III price spread was Rs 1105 followed by channel I and channel II Rs. 574.8 and 421.24 , respectively.

\section{Introduction}

India ranks first in the area under groundnut and second in groundnut production. The major groundnut growing states are Gujarat, Tamil Nadu, Andhra Pradesh, Karnataka and Maharashtra. Groundnut occupies first rank in oilseed crop in India with respect to area and production. In Maharashtra, groundnut is dominant oil seed crop, which is cultivated in all seasons to meet deficiency of edible oil. Mostly groundnut varieties used in
Maharashtra are TAG-24, Phulevyas, TG-26, JKG-194, SB-11 TAG-26. The yield level of kharif groundnut is $15-20$ quintals per hectare and summer groundnuts produces about 25-30 quintals per hectare.

The groundnut production in India was 7180.5 thousand tones in 2015-16 w. It decreased by -221.2 thousand tones as compared to the groundnut production of 7401.7 thousand tones in the year 2014-15 Thus, the annual decrease recorded in the year 
2015-16 was $-2.99 \%$ There was 9 states having groundnut production of more than 100 tonnes Viz. Gujarat, Rajasthan, Tamil Nadu Andhra Pradesh, Karnataka, Madhya Pradesh, Maharashtra, West Bengal, and Telangana in 2015-16 Groundnut crop is cultivated in all the districts of the state. Groundnut is generally grown in rainy season. Gujarat tops with 27.87 percent of total production followed by Andhra Pradesh 24.19 percent, Tamil Nadu 14.84 Percent and Karnataka 1095 percent.

\section{Materials and Methods}

Multistage sampling design was adopted in selection of district, tehsils and villages. In all, 60 wheat growers were selected for the study. Tabular analysis, frequency and percentage methods were used to analyze and compare the data in present study. Marketing cost and market margin of different functionaries were estimated from the data collected from them. The data were collected during the year 2016-17.

Marketing cost and market margin was worked out from actual data collected from market intermediaries. Marketing cost incurred by producer was estimated from the data collected from selected cultivators for the present. Price spread of the producer showed the difference between net price received by the producer in the assembling market and price paid by ultimate consumer to produce in the retail market. It includes all the market charges incurred by the producer, wholesaler, retailer and trader as well as profit margin at wholesaler, retailer and trader. Producer's share in consumer's rupee is very helpful in deciding the appropriate strategies for reducing the marketing cost in the present study. It is price received by the farmer expressed as a percentage of the retail price, i.e. price paid by the consumer. If price is the retail price the producer share in consumer's rupee (Ps) is expressed as follows.
$\mathrm{PS}=$

Net price received by the producer

Price paid by the consumer

\section{Results and Discussion}

Marketing cost, margin and price spread of groundnut production

Marketing channels reveal that how produce passes through different agencies from producer to final consumer. In the study area following prominent channels were observed in the marketing,

Channel-I - Producer- village traderwholesaler- oil processor (consumer)

Channel- II- Producer- wholesaler- oil processor (consumer)

Channel-III- Producer- oil processor (consumer)

\section{Production, retention and marketed} surplus of summer groundnut marketing

Production, retention and marketed surplus of wheat sold through different channels were calculated and are presented in Table 1. Production of TAG-24 summer groundnut was 29.50 quintals on 1.64 hectares and SB11 summer groundnut was 32.05quintals on 1.15 hectares its retention for home on TAG24 was 2.95 and SB-11 was 2.25 quintals. The results revealed that quantity of TAG-24 summer groundnut as12.10, 9.25 and 4.65 quintals were marketed through channel-III, channel-II, and channel-I with percentage 41.00, 30.45 and 16.30, respectively. SB-11summer groundnut was 12.40, 11.45 and 2.55 through channel-I, II, III, respectively. Thus total marketed surplus of TAG-24 and SB-11summer groundnut was 96.61 i.e. 89.39 per cent, respectively. 
Marketing cost of summer groundnut incurred by different intermediaries

\section{Producer}

Item wise per quintal cost of marketing of groundnut incurred by producer in different channels was calculated and presented in Table 2. The cost incurred by the producer was the highest with Rs.144.4 per quintal in channel-III followed by 73.18 in channel-II and 69.18 per quintal in channel-I. It was observed that, the proportionate expenditure in the total cost was highest on transportation charges in channel-I (43.03 per cent) followed by losses (21.15 per cent). In channel-II share was highest on Transportation charges (44.76per cent), followed by losses charges (20.36 per cent). In channel-III share was highest on commission charges (33.24) transportation charges (24.24 per cent).

\section{Wholesaler}

Per quintalcost of marketing of wheat incurred by wholesaler channel-II was calculated and presented in Table 3. The result revealed that total cost wasRs.133.78 and 146.15 in channel-I and channel-II. In which share of market fee was high as 18.68 and 20.52 per cent followed by shop tax 24.29 and 23.60 per cent, 16.11 per cent storage charges in channel-II. Then, electricity charges and labour charges was 0.97 and 1.36 per cent, 6.68 and 7.69 license charges, 18.68 and 20.52 per cent market fees in channel-II and channel-III respectively.

\section{Village trader}

Per quintal cost of marketing of incurred by village trader were calculated and presented in Table 4. The total cost incurred by village trader accounted for Rs. 66.47and 69.97 per quintals in channel-I and channel-II. The share of expenditure in the total cost was the highest on transportation charges 42.13 and 42.88 per cent in channel-I and channel-II followed by, labour charges 21.06 and 21.44 per cent in channel-I and channel-II, loses19.56 and 19.29 per cent, in channel-I and channel-II respectively.

Table.1 Production, retention and marketed surplus of summer groundnut marketing

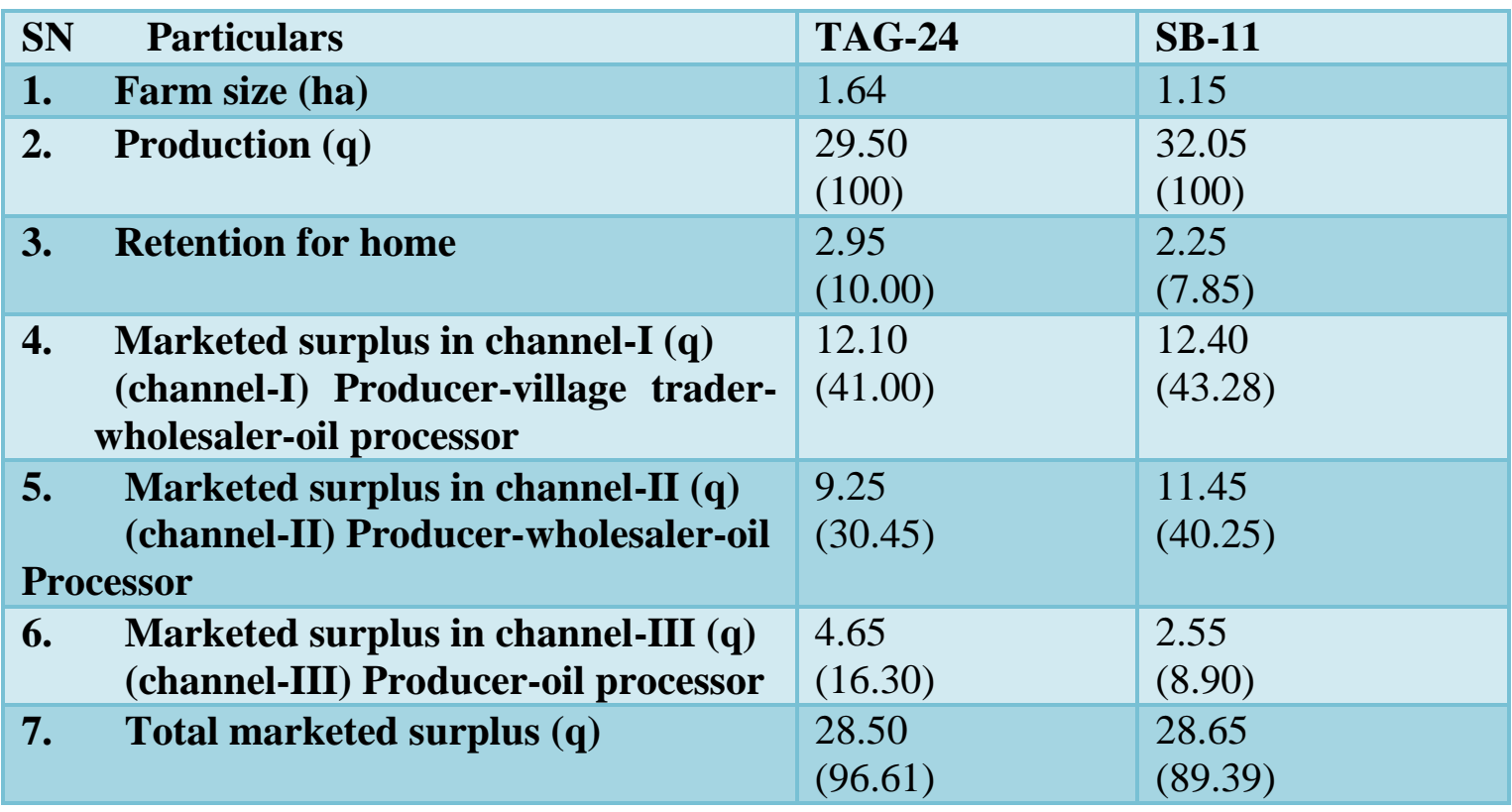

Note: (Figures in the parentheses indicate percentages to total) 
Table.2 Marketing cost incurred by producer

\begin{tabular}{|l|l|l|l|l|}
\hline S N & Particular & Channel-I & Channel-II & Channel-III \\
\hline $\mathbf{1}$ & Labour charges & 13 & 14 & 15 \\
& & $(18.65)$ & $(18.99)$ & $(10.39)$ \\
\hline $\mathbf{2}$ & License & 0.15 & 0.15 & 0.15 \\
& & $(0.22)$ & $(0.20)$ & $(0.10)$ \\
\hline $\mathbf{3}$ & Shop tax & 0.80 & 0.80 & 0.80 \\
& & $(1.15)$ & $(1.09)$ & $(0.55)$ \\
\hline $\mathbf{4}$ & Weighing charges & 0.50 & 0.50 & 0.50 \\
& & $(0.72)$ & $(0.68)$ & $(0.35)$ \\
\hline $\mathbf{5}$ & Loading \& unloading & 10 & 10 & 10.5 \\
& & $(14.34)$ & $(13.56)$ & $(7.27)$ \\
\hline $\mathbf{6}$ & Transport charges & 30 & 33 & 35 \\
& & $(43.03)$ & $(44.76)$ & $(24.24)$ \\
\hline $\mathbf{9}$ & Losses & 15 & 15 & 6.62 \\
& & $(21.51)$ & $(20.36)$ & $(4.59)$ \\
\hline $\mathbf{1 0}$ & Commission & - & - & 48 \\
& & & & $(33.24)$ \\
\hline $\mathbf{1 1}$ & Market fee & - & - & 27.56 \\
& & & & $(19.09)$ \\
\hline & Total cost incurred by & 69.18 & 73.18 & 144.4 \\
& producer & $(100)$ & $(100)$ & $(100)$ \\
\hline
\end{tabular}

Table.3 Marketing cost incurred by wholesaler

\begin{tabular}{|c|c|c|c|}
\hline SN & Particulars & Channel-II & Channel-III \\
\hline 1. & Labour charges & $\begin{array}{l}11.44 \\
(8.55)\end{array}$ & $\begin{array}{l}18 \\
(12.31)\end{array}$ \\
\hline 2. & Transport charges & $\begin{array}{l}12.39 \\
(9.26)\end{array}$ & $\begin{array}{l}19.25 \\
(13.17)\end{array}$ \\
\hline 3. & License charges & $\begin{array}{l}8.94 \\
(6.68)\end{array}$ & $\begin{array}{l}11.25 \\
(7.69)\end{array}$ \\
\hline 4. & Electronic charges & $\begin{array}{l}1.30 \\
(0.97)\end{array}$ & $\begin{array}{l}2.00 \\
(1.36)\end{array}$ \\
\hline 5. & Shop tax & $\begin{array}{l}32.50 \\
(24.29)\end{array}$ & $\begin{array}{l}34.50 \\
(23.60)\end{array}$ \\
\hline 6. & Communication charges & $\begin{array}{l}9.30 \\
(6.95)\end{array}$ & $\begin{array}{l}10.56 \\
(7.22)\end{array}$ \\
\hline 7. & $\begin{array}{l}\text { Depreciation, repaired or fixed } \\
\text { cost@ 10\% }\end{array}$ & $\begin{array}{l}0.31 \\
(0.23)\end{array}$ & $\begin{array}{l}1.54 \\
(1.05)\end{array}$ \\
\hline 8. & Interest on fixed asset @ 11\% & $\begin{array}{l}0.60 \\
(0.44)\end{array}$ & $\begin{array}{l}0.80 \\
(0.54)\end{array}$ \\
\hline 9. & Market fee & $\begin{array}{l}25 \\
(18.68)\end{array}$ & $\begin{array}{l}30 \\
(20.52)\end{array}$ \\
\hline 10. & Other & $\begin{array}{l}12.00 \\
(8.96)\end{array}$ & $\begin{array}{l}18.25 \\
(12.48)\end{array}$ \\
\hline & TOTAL & $133.78(100)$ & 146.15 \\
\hline
\end{tabular}


Table.4 Costs incurred by the village trader (Rs/qt)

\begin{tabular}{|l|l|l|l|}
\hline S N & Particular & Channel-I & Channel-II \\
\hline $\mathbf{1}$ & Labour charges & 14 & 15 \\
& & $(21.06)$ & $(21.44)$ \\
\hline $\mathbf{2}$ & License & 0.12 & 0.12 \\
& & $(0.18)$ & $(0.17)$ \\
\hline $\mathbf{3}$ & Shop tax & 0.60 & 0.60 \\
& & $(0.90)$ & $(0.86)$ \\
\hline $\mathbf{4}$ & Electric charges & 0.50 & 0.50 \\
& & $(0.75)$ & $(0.71)$ \\
\hline $\mathbf{5}$ & Storage & 10 & 10 \\
& & $(15.04)$ & $(14.29)$ \\
\hline $\mathbf{6}$ & Transport charges & 28 & 30 \\
& & $(42.13)$ & $(42.88)$ \\
\hline $\mathbf{7}$ & Depreciation & 0.11 & 0.11 \\
& & $(0.17)$ & $(0.16)$ \\
\hline $\mathbf{8}$ & Interest on fixed assets & 0.14 & 0.14 \\
& & $(0.21)$ & $(0.20)$ \\
\hline $\mathbf{9}$ & Losses & 13 & 13.5 \\
& & $(19.56)$ & $(19.29)$ \\
\hline & Total cost incurred by village trader & $66.47(100)$ & $69.97(100)$ \\
\hline
\end{tabular}

(Note: Figures in parentheses indicate percentage to total)

Table.5 Per quintal marketing cost, marketing margin and price spread in Summer Groundnut marketing

\begin{tabular}{|c|c|c|c|c|}
\hline SN & Particular & Channel-I & Channel-II & Channel-III \\
\hline 1. & $\begin{array}{l}\text { Net price received by producer } \\
\text { (producer's share in consumer rupee) }\end{array}$ & $\begin{array}{l}3775.70 \\
(86.78)\end{array}$ & $\begin{array}{c}3679.24 \\
(97.94)\end{array}$ & $\begin{array}{l}3545.25 \\
(94.65)\end{array}$ \\
\hline 2. & Cost incurred by producer & $\begin{array}{c}69.18 \\
(1.7)\end{array}$ & $\begin{array}{l}73.18 \\
(1.94)\end{array}$ & $\begin{array}{l}144.4 \\
(4.03)\end{array}$ \\
\hline 3. & Price paid by village trader & $\begin{array}{c}3880.50 \\
(89.50)\end{array}$ & - & - \\
\hline 4. & Cost incurred by village trader & $\begin{array}{c}66.47 \\
1.52\end{array}$ & $\begin{array}{c}66.97 \\
1.78\end{array}$ & - \\
\hline 5. & Margin of village trader & $39.35(0.90)$ & - & - \\
\hline 6. & Price paid by wholesaler & - & $\begin{array}{c}3756.50 \\
(100)\end{array}$ & $\begin{array}{c}3745.50 \\
(100)\end{array}$ \\
\hline 7. & Cost incurred by wholesaler & - & $\begin{array}{l}133.78 \\
(3.26)\end{array}$ & $\begin{array}{l}146.15 \\
(3.14)\end{array}$ \\
\hline 8. & Margin of wholesaler & - & $\begin{array}{l}281.09 \\
(6.85)\end{array}$ & $\begin{array}{l}783.95 \\
(16.85)\end{array}$ \\
\hline 9. & Price paid by processer & $\begin{array}{c}4350.50 \\
(100)\end{array}$ & $\begin{array}{c}4100.48 \\
(100)\end{array}$ & $\begin{array}{c}4650.00 \\
(100)\end{array}$ \\
\hline 10. & Total marketing cost & $\begin{array}{l}135.65 \\
(23.59)\end{array}$ & $\begin{array}{l}140.15 \\
(33.27)\end{array}$ & $\begin{array}{r}290.55 \\
(1.03)\end{array}$ \\
\hline 11. & Total market margin & $\begin{array}{l}438.65 \\
(76.31)\end{array}$ & $\begin{array}{l}274.62 \\
(65.19)\end{array}$ & $\begin{array}{c}812.2 \\
(73.50)\end{array}$ \\
\hline 12. & Price spread & $\begin{array}{l}574.8 \\
(100)\end{array}$ & $\begin{array}{c}421.24 \\
(100)\end{array}$ & $\begin{array}{l}1105 \\
(100)\end{array}$ \\
\hline 13. & Market efficiency & 7.56 & 9.73 & 4.20 \\
\hline
\end{tabular}


Storage charges 15.04 and 14.29 per cent, Electric charges 0.75 and 0.71 per cent and shop tax 0.90 and 0.86 per cent in channel-I and channel-II respectively.

Per quintal marketing cost, marketing margin and price spread in summer

\section{Groundnut marketing}

Per quintal marketing cost, marketing margin and price spread in wheat marketing with respect to different channels was estimated and it presented in Table 5. In channel-III price spread was Rs. 1105 followed by channel II and channel-I Rs. 574.8 and 421.24, respectively. In channel-I, Producer and consumer were the two intermediaries while in channel-II, Producer- wholesalerretailer and consumer was intermediaries. In channel-III Producer- retailer and consumer is the channel, it was observed that price spread was Rs. 1105 in channel-III followed by that of Rs574.8 in channel-II and Rs. 421.24 in channel-I. Thus, net price received by producer was Rs.3775.70 in channel-I, followed by Rs. 3679.24 in channel-II and Rs. 3545.25 in channel-I.

The conclusion of the study is as follows

1. The marketing cost incurred by summer groundnut producer was the highest in Channel - III as compare to channel I \& II.
2. Producer's share in consumer's rupee was highest in channel-II i.e. 97.94 per cent.

Net price received by producer was Rs.3775.70 in channel-I, followed by Rs. 3679.24 in channel-II and Rs. 3545.25 in channel-I.

\section{References}

Mane, P.S., Pawar, B.R. and Dahiwade, P.M. (2014) Price spread in marketing channels of summer groundnut in Maharashtra. Agriculture Update, 9(2): 201-203.

Makadia, J.J., Patel, K.S. and Ahir, N.J. (2012). Economics of production and marketing of summer groundnut in Tapi district of South Gujarat, International Research Journal of Agricultural Economics \&Statistics., 3 (1): 18-22.

Shelke R. D, D. V. Nagure and S. N. Patil (2009) Price spread \& marketing pattern in Maharashtra state', Agriculture update., 4(3\&4): 376-378.

SugrivKumarMaurya, R.R.Kushwaha, K.K.Mourya and Sarvesh Kumar (2017) Price spread and marketing efficiency of groundnut marketing in Gorakhpur Districts of Eastern (U.P). Journal of Pharmacognosy and Phytochemistry, 6(6): 712-715.

Vinod Kumar, (2010) A study on marketing cost, price spread, price behaviour and

Marketing efficiency in Rajasthan. Indian $J$. Agric. Mktg. 24(2): 152-163.

\section{How to cite this article:}

Chatse, D.B., D.S. Perke and Selke, R.D. 2018. Economic Analysis of Marketing of Summer Groundnut in Hingoli district of Maharashtra State. Int.J.Curr.Microbiol.App.Sci. 7(08): 20222027. doi: https://doi.org/10.20546/ijcmas.2018.708.233 